\title{
Distal Bile Duct Cancer pTO TNM Finding v7
}

National Cancer Institute

\section{Source}

National Cancer Institute. Distal Bile Duct Cancer pTO TNM Finding V7. NCI Thesaurus.

Code C90247.

Distal bile duct cancer with no evidence of primary tumor. (from AJCC 7th Ed.) 